\title{
Intervening Variables and Savings Mobilization of Staff Owned Cooperative Societies in Nasarawa State Public Institutions (A Case Study of Naspoly Staff Multipurpose Cooperative Society Nasarawa State Nigeria)
}

\author{
Dauda Ibrahim A. Ph.D. CNA \\ Department of Accountancy, Nasarawa State Polytechnic, Lafia. \\ Nasarawa State, Nigeria \\ Dauda I. Musa M.Sc. CNA \\ Department of Accounting \& Bus. Admin, Fed. Uni. \\ Kashere, Gombe State, Nigeria
}

\begin{abstract}
This paper examined the intervening variables affecting the mobilization of savings of Staff owned Cooperative Societies in Nasarawa State Public Institutions and their effects on the savings mobilization. It was a survey research that focused on the Naspoly Staff Cooperative Society, Nasarawa State Polytechnic Lafia, Nasarawa State Nigeria. Questionnaire was administered to a randomly sampled 250 members from the 380 registered members as at December 2018, with the view to confirming that the following variables (family size, income level, number of children in school and market situation) affects savings mobilization of staff owned cooperative societies in public institutions in Nasarawa State. Data collected were analyzed using descriptive statistics and The Pearson Product Moment Correlation. Findings from results of the study showed that, the identified variables intervenes in savings activities of staff members, it actually hampered the society's efforts in mobilizing savings. It conclude that, although these intervening variables are individualistic, they by extension affect the savings mobilization of the cooperative societies. In line with the findings of the study, it was recommended therefore, that With due consideration of the income factor which is a prime determinant of savings, government as a whole should consider improving staff take home and adopt measures that will ensure price control in the market. Government should ensure that the timing for review of staff salaries be reviewed two to three years looking at the rate of inflation in Nigeria.
\end{abstract}

Keywords: Intervening Variables, Savings Mobilization, Staff Cooperative Societies, Public Institutions,

\section{INTRODUCTION}

Economic prosperity of public servants in the public tertiary institutions in Nasarawa State can only be achieved by putting in place well focused programmes aiming at addressing the gap created by the inadequacy in the income generated from their fixed salaries. Staff Cooperative Societies are considered as the most significant programme adopted by member staff, which enhances their leaving standards, by providing for savings and credit services which will enable them financial strength to own assets, comfortably cater for their family's needs and be more self-reliant through some mini investments. Following the words of Harrod and Domar (1957) as cited in Otto and Ukpere, (2011), savings mobilization and subsequent investment is the key to economic growth and development. The cooperative societies primarily mobilizes savings form members and other sources which are in turn used to finance their needs by granting loans facilities with minimal conditions and cost. 
Saving is important as it assumed the basic source of supply of capital for investment whether micro, small or medium for income generation. Economists according to Nwankwo, Ewuim and Asoyo (2013), have established the functional relationship between income and savings. Although, as public servants, members are expected to only concentrate on their primary responsibilities in their various offices, their various take homes no longer take them home as expected, therefore the need for additional source. While cooperative societies created by staff of the various public institutions are primarily to cover the existing gap created by the insufficiency of salaries in the hard economy situation despite the assumed jumbo pay to staff of the Public institution in Nasarawa State, they appeared to have failed to provide savings facilities that are acceptable and attractive to these staff. This is because a good number of these staff still patronized the formal savings and credit institutions like banks and micro finances. In the opinion of this study, there may be certain existing intervening variables that affects savings mobilization of cooperative societies in tertiary institutions in Nasarawa State. This paper having noted this gap, tried to identify these variables and their effects on savings of cooperative societies in the tertiary institutions.

\section{The Study Objective}

This Study mainly examined the intervening variables affecting the mobilization of savings of staff cooperative societies in Nasarawa State public institutions and their effects on savings mobilization. Specifically, it is to:

i investigate whether the following identified variables (family size, income level, number of children in school and market situation) actually affects savings mobilization of staff cooperative societies in Nasarawa State public institutions; and

ii examine the extent at which the variables (family size, income level, number of children in school and market situation) affect savings mobilization of staff cooperative societies in Nasarawa State public institutions.

\section{Research Question}

The following questions are used as guide in funding solution to the study problem.

i Will family size, income level, number of children in school and market situation affect the mobilization of saving by staff cooperative societies in Nasarawa State public institutions?

ii To what extent does these variables (family size, income level, number of children in school and market situation) affect savings mobilization of Staff cooperative societies in Nasarawa State public institutions?

\section{Research Hypothesis}

The study is guided by the following hypothesis formulated in null form.

Ho1: Family size, income level, number of children in school and market situation does not significantly affect savings mobilization of staff cooperative societies in Nasarawa State public institutions.

\section{Conceptual Review}

\section{LITERATURE REVIEW}

For rainy days and future investment purposes both in short or long term, certain portion of people's income are put aside as savings. Individual members of cooperative societies uses the cooperatives as a medium through which savings are achieved. The cooperative societies in the other hand serves as a custody to its members. According to FAO (1995) as cited in Nwankwo, Ewuim, \& Asoya (2013), savings are resources which one decides to put aside for investment purposes and not for luxury. What people save, avoiding to consume all their income, is called 
"personal savings". These savings are for future use or be actively invested in houses, real estate, bonds, shares and other financial instruments. A study by EFINA (2011) found both savers and non-savers agreeing that personal savings plays an important role in people's lives. Savings ensures the continuity of a business as it provides fresh funds to grow the business. It helps in the attainment of set goals, and at the same time encourages financial discipline. Savings also act as a means of insurance, so that emergencies can be dealt with as they arise. These principles generally can be applied on public servants who also see savings as means preparation for future and or a pool which can be used in acquiring such assets and other demands such as children tuitions which ordinarily cannot be acquired through the salaries.

Although savings are categorized into National savings, personal savings, business savings and public savings (Nwankwo et al, 2013), this study considers personal servings which is the basis for cooperative savings for members. Personal savings, according to Piana (2003) has identified a tri-lateral relationship among savings, consumption, and income is the key determinant of the amount of personal savings. The decision to buy goods and services refers to consumption and it negatively affects savings. Savings on the other hand can be as a result of expectation of negative outcome about future income; that is a situation where one is afraid of being dismissed or afraid of hardships coming.

\section{Factors that Affect Personal Savings}

The Following influencing factors affect personal savings as adopted by FAO (1995) and cited in Nwankwo et al, 2013

(a) Savings depend on income. Theoretically, more income means more capacity to save. But without a decision this may not be so.

(b) Saving consciousness/willingness is decided not by income, but by decision and forming a habit. A person can have a little income, but if she has decided to save and form the habit, she will have more savings than the person with a higher income who has not decided to save.

(c) Savings depend on the determination/persistence of a person to get out of poverty.

(d) Savings depend on factors such as family size, slack period in the agricultural season.

(e) By saving as a group, it is easier to make savings a habit. We seem to be helped by the fact that there are others who are doing the same thing we do and that together we are able to do things better.

(f) Savings deposited in the group fund is not as easily spent as when I save and keep myself; I am able to participate in the benefits from the group since I can borrow from the group fund and benefit from ideas and get encouragement from the group;

(g) By saving in the group, each member is equal to everyone and because membership is voluntary, each one therefore has equal right in decision making on how the savings will be utilized.

(h) The savings fund belongs to the group and therefore members are the only ones who can decide on how this will he used.

\section{Concept of Savings Mobilization}

For the purpose of promoting thrift among members by affording them an opportunity for accumulating savings and paying reasonable interest without risk on such savings, the cooperative societies create source of funds from which it can afford relief to its members in need by making loans to them for productive and provident purposes at a fair and reasonable rates of interest and with easy terms of repayment. Mobilization of savings according to Cheruiyot, Kimeli and Ogendo (2012), also include encouraging members to save through continuous education of members on how savings can be made on regular basis and the way they use their savings and provide service to its members such as financial counseling so that 
the members can solve most of their financial problems, and the risk of management service to ensure the safety of members' savings and loans. Others include: accessibility and interest rates on saving and lending is low and affordable, members are taught how to handle their finances in a responsible manner.

\section{Intervening Variables to Savings Mobilization of Cooperative Societies}

Although Cheruiyot et al (2012) adopted five (5) Intervening variables which includes personal factors such as family size, attitude, proximity, income level and number of children in school, for the purpose of this study, only four (4) were considered. This study believed attitude and proximity are affected by these four variables (family size, income level and number of children in school). Family Size: the size of the family of members of cooperative societies directly affects their personal savings in the event that it increases without a corresponding increase in income of the members.

Income Level: the income level of individual, determines his consumptions thereby affects his level of savings. Although for salary earners, they have a fixed income but the value of such income may be affected by changes in market situation.

Number of Children in School: the higher the number of children in school, mean high commitment in terms of school fees and other items for use in the schools. This may affects the savings ability, since there may be no increase in the salary income.

Market Situation: changes in the prices of items in the market especially food stuff and other needed items in the family may affects the savings as members will want to meet the immediate demands of their families.

Cooperative Society: Derived from the word cooperation (work together), and from the Latin word, co-operari co means 'with' and Operari means to 'work'. The background therefore means that, those who want to work together with some common economic objective can form a society, which can be termed cooperative society." it is a voluntary association of persons who work together to promote their common economic interest. It is, according to Umoru (2016) defined as a voluntary association of persons who work together to promote their economic interest of supporting each other financially.

According to Adesina as cited in Oroka (2016), cooperative society as an enterprise where people voluntarily conglomerate together on the ground of equality having participation in management to promote common economic interests, using equal voice, making approximately equal or proportional contributions to capital and drawing equal service and benefit from it and run for those who use its services. The International Cooperative Alliance (ICA 2014) defined it as an autonomous association of persons united voluntarily to realize their common economic, social and cultural needs and aspirations through a jointly owned and democratically controlled organization. Kassalil, Adejobi and Okparaocha (2013) Stressed cooperative as a business entity which seeks to maximize profit to ensure growth of the social enterprise, grow members" business and alleviate poverty of members, shareholders.

It is therefore clear that, cooperatives societies are established by like-minded people for the aim of improving their standard of living while reaping from the social service provided. And that its draw its capital base from the contribution of members mostly. The basic philosophy of cooperative movement hint on service and the well-being of members and guided by seven 
cooperative principles that have been globally accepted and adopted by the International Cooperative (ICA 2014).

\section{Cooperative Society and the Promotion Savings}

Cooperative Societies are autonomous association of persons united voluntarily to meet their common economic and social needs through a jointly owned democratically controlled enterprise or business. It is among its functions, mobilized savings and accord member easy access to loans on a way of enhancing their socio-economic wellbeing. It is an organization owned by people living in one area such as farmers or people working together. It encourage savings and members save within the framework of the cooperative, knowing that he/she will receive a suitable return for his effort, in the form of interest on his savings in addition to other benefits. The cooperative societies also assumed the role of mobilizing savings from the lower to middle wealth segments of the population and channeling them to a similar class of borrowers in the form of loans for investment and consumption.

Cooperative Societies play an important role in the socioeconomic development of the people, they provide avenues for members to save regularly and then borrow for productive and welfare purposes guided by the values of the cooperative movement world over (Ahimbisibwe, 2007). It can be formed by any group of people who either has common bond (like in the case of one employer), or people with similar objectives. Examples of such people are Government employees, employees of government parastatals, teachers, nurses, doctors, traders, mall workers, municipal workers, tax workers, employees of private commercial companies, parliamentarians, hawkers and domestic workers (Cheruiyot etal, 2012). It gives a sense of believe and trust in members hence it will be managed by elected members representatives

\section{Theoretical Framework}

This study was underpinned by four (4) theories as adopted in Nwankwo et al, (2013). They include; those of Keynes (absolute income theory), Friedman (permanent income theory) Modigliani (lifecycle income theory) and Duesembery (relative income theory)

\section{Keynes - absolute income theory}

it states that, as household's income increases at any given time, it consumes and saves more. Although economists agree that income and/or wealth is the main driving force behind consumption and thus saving, they however disagree on which income should be applied. The Keynesians used current/absolute income,

\section{Friedman's- permanent income theory}

This is based on two concepts: the transitory income and the permanent income. It believes that, the transitory income, or windfall income, is a temporary income change, which leads to an increase in saving rather than consumption. While the permanent income is the income the household feels sure of getting. This permanent income increases a household's consumption without changing its saving level, and can even decrease the saving level.

\section{Moddigliani and Brumber's- lifecycle income theory:}

it holds that, the consumption patterns of a household depend on the stage of its lifecycle. Over the lifecycle, income follows consumption with a similar hump or bell-shaped pattern, with the difference as (dis)saving. Consumption exceeds saving, (thus creating (dis)saving or probably borrowing) when a household is younger; saving reaches its peak, exceeding consumption, for a household in middle age, and then the household lives off of its accumulated wealth/saving during retirement. Thus the propensity to save depends on age and differs systematically across age-specific cohorts. 


\section{Dusembery's- relative income theory}

It is based on the inelasticity of consumption patterns relative to a change in income, and concludes that consumption is always relative to the household's income, and that of their friends. Credit makes it possible for people to keep their consumption level up while their income goes down.

Clearly, an understanding of these theories will enable an enhanced appreciation of income as the main driving force behind savings decisions. It is the contention of this study, against the background of these theories, that if and when credit societies 'activities promote income level, there are bound to be positive outlook in personal savings of members. The identified variables are all dependent on the level of income, hence the study is anchored on the four theories.

\section{Review of Empirical Studies}

Nwankwo, Ewuim and Asoyo (2013) assessed the effect of cooperative on the savings behavior of members. The study was carried out in Oyi LGA of Anambra State Nigeria with a randomly selected 195 members of credit cooperatives for data source. Analysis of data was with descriptive statistical tools and multiple regression model the study found that cooperative membership impacted positively on the savings behavior of members and that older members had more savings than newer members. While this could be obvious naturally, the study did not considered other control variables that may significantly affect the savings pattern of members.

Onafowokan (2013) examined the extent to which savings products offered by cooperative societies in some parts of Nigeria meet the financial needs of the rural dwellers. The study used the data from interviews and focus group discussions from randomly selected members of cooperative societies in six local governments' council in Anambra State Nigeria. The data are analyzed using percentages, content analysis and quotation. The study found that the savings product helps to inculcate a good savings habit among the participants because they find it easier to save now than when they were introduced to the program.

Cheruiyot, et al (2012) determined the effect of cooperative strategies on members' savings mobilization and analyze the effect of intervening factor (family size, attitude, and income level) on savings mobilization. The study utilized a sample of 30 Savings and Credit Cooperatives in Kenya out of 2,500 and 180 Savings and Credit Cooperatives members out of 150,000 in Nairobi area which were selected through simple random sampling method. A semi structure questionnaire was used to collect data from the respondents. Data was analyzed using a multiple linear regression model. The study revealed that training requirement had an average positive influence on saving mobilization, while investment opportunities and intervening Variables had a strong positive influence on saving mobilization.

\section{METHODOLOGY}

A survey research design was used in the study hence data were sourced from responses of members of the Naspoly Staff Multipurpose Cooperative Society. The technique for collecting the data was questionnaires and the questions were well examined and made unambiguous. The population of the study comprised 380 members of the Naspoly Staff Multipurpose Cooperative Society out of which 250 members were sampled randomly for the study. The instrument for this study was an eight items structured questionnaire; 4 each derived from the 2 research questions, with a response option of a 4-point Likert scale of strongly agree (4), agree (3), disagree (2), and strongly disagree (1). Out of the 250 copies of the questionnaire administered, 232 with valid responses were returned and analysed using the Descriptive 
statistics. The Pearson Product Moment Correlation method was used to confirm the hypotheses of the study.

\section{Data Analysis Procedure}

i. The four point Likert scales of SA, A, D and SD are used with respective grades (points) $4,3,2$ and 1 as, the multipliers of each response from the respondents (f4, f3, f2, f1, )

ii. The Cut off Score is obtained as $=$ Sum of the Grades/ Number of Grades $=4+3+2+1 / 4=$ 2.50

Arithmetic mean was used to analyze each question in the questionnaire at a decision point of 2.50 and above as agree and below 2.50 as disagree.

\section{Results and Discussion}

Analysis based on research Question/hypothesis 1.

Table 1: On whether family size, income level, number of children in school and market situation can affect the mobilization of saving by staff cooperative societies in Nasarawa State Public Institutions.

\begin{tabular}{|l|c|c|c|c|c|c|}
\hline \multicolumn{1}{|c|}{ STATEMENT } & $\begin{array}{c}S A \\
4(f 4)\end{array}$ & $\begin{array}{c}A \\
4(f 3)\end{array}$ & $\begin{array}{c}\text { DA } \\
4(f 2)\end{array}$ & $\begin{array}{c}\text { SD } \\
4(f 1)\end{array}$ & MEANS & RANKING \\
\hline $\begin{array}{l}\text { Increase in the size of the family of a staff } \\
\text { member of the staff cooperative society can } \\
\text { affects mobilization of savings by the society. }\end{array}$ & 280 & 450 & 20 & 2 & 3.24 & 4 \\
\hline $\begin{array}{l}\text { Changes in the income level of a staff member } \\
\text { of the staff cooperative society can affect } \\
\text { savings mobilization by the society. }\end{array}$ & 520 & 296 & 2 & 2 & 3.53 & 1 \\
\hline $\begin{array}{l}\text { The number of children in school of a staff } \\
\text { member family of the staff cooperative } \\
\text { society can affect savings mobilization by the } \\
\text { society. }\end{array}$ & 408 & 300 & 40 & 10 & 3.37 & 2 \\
\hline $\begin{array}{l}\text { Changes in market situation in relation to } \\
\text { prices of goods can also affect saving } \\
\text { mobilization of the staff cooperative society }\end{array}$ & 392 & 306 & 50 & 7 & 3.25 & 3 \\
\hline
\end{tabular}

Source: Field survey 2019.

Table 1 above indicates respondents' response on whether family size, income level, number of children in school and market situation can affect the mobilization of saving by staff cooperative societies in Nasarawa State Public Institutions. Revealed was that family size, income level, number of children in school and market situation can affect savings mobilization of staff cooperative societies in the Nasarawa State Public Service. This was predicated on the fact that the mean score obtained for each statement is greater than cut off mean of 2.50 
Analysis based on research Question/hypothesis 2 .

Table 2: The extent at which family size, income level, number of children in school and market situation affect savings mobilization of Staff cooperative societies in Nasarawa State public institutions?

\begin{tabular}{|l|c|c|c|c|c|c|}
\hline \multicolumn{1}{|c|}{ STATEMENT } & $\begin{array}{c}S A \\
4(f 4)\end{array}$ & $\begin{array}{c}A \\
4(f 3)\end{array}$ & $\begin{array}{c}\text { DA } \\
4(f 2)\end{array}$ & $\begin{array}{c}\text { SD } \\
4(f 1)\end{array}$ & MEANS & RANKING \\
\hline $\begin{array}{l}\text { The size of the family of a staff member of the } \\
\text { Staff Cooperative Society can significantly } \\
\text { affects mobilization of savings by the society. }\end{array}$ & 208 & 144 & 180 & 42 & 2.47 & 4 \\
\hline $\begin{array}{l}\text { The level of income of a staff member of the } \\
\text { staff cooperative society can significantly affect } \\
\text { savings mobilization by the society. }\end{array}$ & 580 & 225 & 20 & 3 & 3.57 & 1 \\
\hline $\begin{array}{l}\text { The number of children in school of a staff } \\
\text { member of the staff cooperative society can } \\
\text { significantly affect savings mobilization by the } \\
\text { society. }\end{array}$ & 316 & 273 & 100 & 12 & 3.02 & 3 \\
\hline $\begin{array}{l}\text { Changes in market situation in relation to prices } \\
\text { of goods can significantly affect saving } \\
\text { mobilization of the staff cooperative society }\end{array}$ & 360 & 300 & 80 & 2 & 3.20 & 2 \\
\hline
\end{tabular}

Source: Field survey 2019.

Table 1 above indicates respondents' response on whether family size, income level, number of children in school and market situation can significantly affect the mobilization of saving by staff cooperative societies in Nasarawa State Public Institutions. This revealed that family size of a staff member of staff cooperative societies in Nasarawa State does not significantly affect savings mobilization of , income level, number of children in school and market situation this was because of the fact that the mean score is 2.47 which was lower than the cut off mean 2.50. However, income level, number of children in school and market situation can significantly affect savings mobilization of staff cooperative societies in the Nasarawa State Public Service. This was based on the fact that the mean score obtained for each statement is greater than the cut off mean of 2.50

\section{Test of Hypothesis}

Ho: Family size, income level, number of children in school and market situation does not significantly affect savings mobilization of staff cooperative societies in Nasarawa State public institutions.

H1: Family size, income level, number of children in school and market situation significantly affect savings mobilization of staff cooperative societies in Nasarawa State public institutions. 
Table 3: Correlations between family size, income level, number of children in school and market situation and savings mobilization of staff cooperative societies in Nasarawa State public institutions.

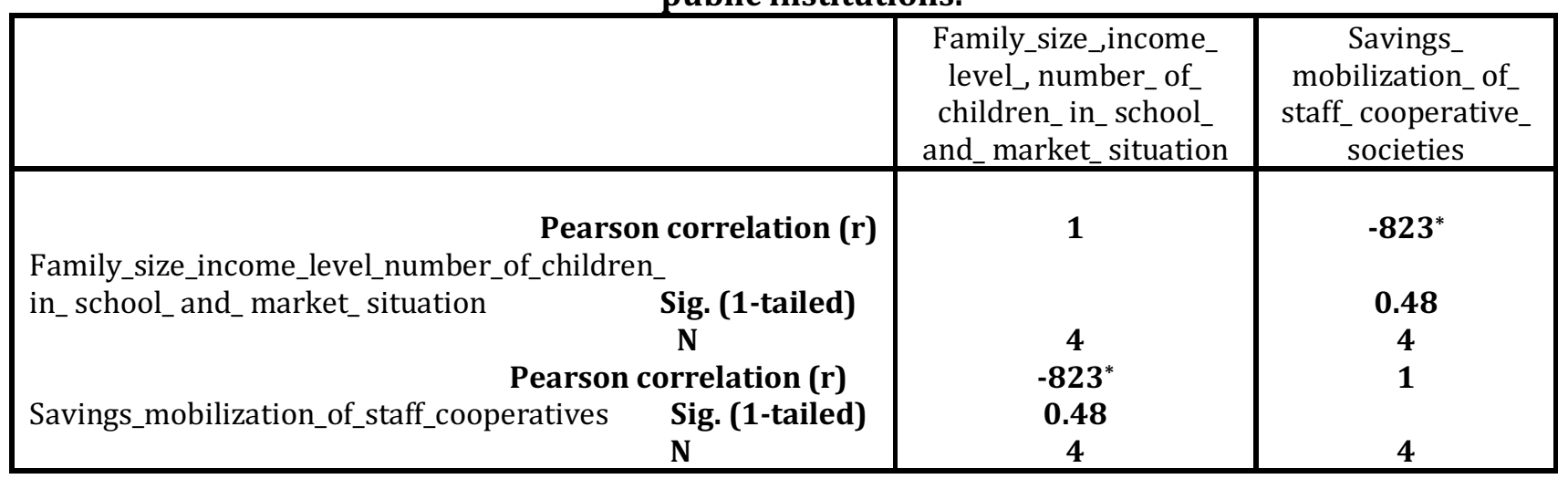

${ }^{*}$ Correlation is significant at the 0.05 level (1-tailed)

Table 3 shows ( $\mathrm{r}=-0.823$, p-value $<0.05)$. Which implies that there is a strong correlation between family size, income level, number of children in school and market situation and savings mobilization of staff cooperative societies in Nasarawa State public institutions. The null hypotheses is therefore rejected and the alternative accepted. It is concluded therefore that Family size, income level, number of children in school and market situation significantly affect savings mobilization of staff cooperative societies in Nasarawa State public institutions.

\section{CONCLUSION}

The paper conclude that, family size, income level, number of children in school and market situation actually intervene in savings mobilization activities of public/civil servants various staff cooperative societies. It actually hampered the society's efforts in mobilizing savings. It conclude that, although these intervening variables are individualistic, they by extension affect the savings mobilization of the cooperative societies.

\section{RECOMMENDATIONS}

In line with the findings of the study, it was recommended therefore, that With due consideration of the income factor which is a prime determinant of savings, government as a whole should consider improving staff take home and adopt measures that will ensure price control in the market. Government should ensure that the timing for review of staff salaries be reduced to two or three years considering the rate/frequency at which prices of goods fluctuate.

\section{References}

Ahimbisibwe, F. (2007). The Effects of Savings and Credit Co-operatives on Members' Saving Culture. Case Study: Ntungamo District. Cooperative Development Department Ministry of Tourism, Trade and Industry, Uganda

Cheruiyot, T. K., Kimeli, C. M., \& Ogendo, S. M. (2012). Effect of Savings and Credit Co-operative Societies Strategies on Member's Savings Mobilization in Nairobi, Kenya, International Journal of Business and Commerce. 1 (11), 4063.

EFINA (2011). Understanding the low income population in Nigeria. Retrieved on March 11, 2018 from http://www.efina.org.ng/assets/Documents/EFInAUnderstanding-the-Low-Income-Population-in Nigeria FDGReportMarch-2011.pdf?

FAO (1995). Breaking through - A manual for field workers and rural women on group formation. Women and Development Programme. China: Food and Agriculture Organisation of the United Nations.

Harrod R. F., \& Domar E. (1957). Essays on the Theory of Economic Growth, Oxford University Press, England. International Cooperative Alliance (ICA) (2014). International cooperative Alliance. Retrieve on 10 December, 2018 from http//www.icu.coop/.ss 
Kassali, I.R., Adejobi, I.A., \& Okparaocha, P. (2013). Analysis of cooperative financial performance in Ibadan Metropolis, Oyo State Nigeria. International Journal of Cooperative Studies, 2(1), 12 - 16.

Nwankwo, F., Ewuim, N., \& Asoya, N. P. (2013). Effect of Cooperatives on the Savings Behaviour of Members in Oyi Local Government Area, Anambra State, Nigeria. International Multidisciplinary Journal, 7 (1), 209-227.

Oroka, V. O. (2016). Cooperatives as a veritable tools for wealth creation and financial stability in our present day economy. A paper presented in a one day seminar organized by Ministry of Commerce Industry Sapele.

Otto G., \& Ukpere, W. I. (2011). Credit and thrift co-operatives in Nigeria: A potential source of capital formation and employment. African Journal of Business Management, 5(14), 5675-5680

Onafowokan, O. O. (2013). Impact of Cooperative Societies Savings Scheme in Rural Finance: Some Evidence from Nigeria. Journal of Economics and Business. XI (1), 77-88.

Piana, V. (2003). Savings Economics Web Institute. Retrieved on 9, April 2016 from http://www.economicswebinstitute.org/glossary/savings.htm

Umoru, D. (2016). The economics of retirement planning and the role of cooperative societies in Nigeria. A paper presented in a one day Seminar organized by ministry of commerce and industry Sapele. Delta State. Nigeria. 